\title{
Primary Soft Tissue Sarcoma and Its Local Recurrence: Genetic Changes Studied by Comparative Genomic Hybridization
}

Pentscho Popov, M.D., Mortti Virolainen, M.D., Ph.D., Erkki Tukiainen, M.D., Ph.D., Sirpa Asko-Scljavaara, M.D., Ph.D., Riikka Huuhtanen, M.D., Ph.D., Sakari Knuutila, Ph.D., Maija Tarkkanen, M.D. Ph.D.

Department of Plastic Surgery (PP, ET, SA-S), Töölö Hospital, Helsinki University Central Hospital; Department of Oncology (MV, RH), Helsinki University Central Hospital; Department of Medical Genetics (SK, MT), Haartman Institute, University of Helsinki; and Laboratory of Medical Genetics (SK, MT), Helsinki University Central Hospital

The aims of this study were to compare genetic aberrations in primary soft-tissue sarcomas and their local recurrences and to evaluate the genetic changes occurring during tumor progression. A primary soft-tissue sarcoma and its subsequent local recurrence were analyzed in 20 tumor pairs by comparative genomic hybridization. The samples were obtained before application of radio- or chemotherapy. Copy number aberrations were detected in $50 \%$ of the primary tumors and in $70 \%$ of the local recurrences. In primary tumors, the mean number of changes was 2.45 (range, 0 to 11 ) whereas in local recurrences, it was 5.05 (range, 0 to 17 ). The mean increase of changes from primary tumor to local recurrence was 2.6 per tumor pair $(P=.02)$. Gains predominated over losses in both primary tumors and their local recurrences. The number of highlevel amplifications was twofold in local recurrences. The most frequent gain affected 5p14-p15.1 ( $10 \%$ of primary tumors, $25 \%$ of local recurrences) and the most frequent loss, 9p (9p21-pter in 5\% of primary tumors; 9p22-pter in $30 \%$ of local recurrences). In conclusion, our results show an increase in the number of genetic changes in local recurrences, due to tumor progression. Loss at $9 p$ and gains at $5 p$ and $20 q$ were more frequent in local recurrences, and high-level amplification of 18p11.3 was not detected in any of the primary tumors. Although all these alterations were not spe-

Copyright (C) 2001 by The United States and Canadian Academy of Pathology, Inc.

VOL. 14, NO. 10, P. 978, 2001 Printed in the U.S.A.

Date of acceptance: June 27, 2001.

The study was supported by the Leiras Research Foundation.

Address reprint requests to: Maija Tarkkanen, M.D., Ph.D., Department of Medical Genetics, Haartman Institute, University of Helsinki, P.O. Box 21, FIN-00014 University of Helsinki, Finland; e-mail: Maija.Tarkkanen@Helsinki.Fi; fax: 358-9-191-26788. cific to local recurrences, they may represent changes important during tumor progression.

KEY WORDS: Comparative genomic hybridization, Local recurrence, Soft tissue sarcoma, Tumor progression.

Mod Pathol 2001;14(10):978-984

Soft-tissue sarcomas (STS) are relatively rare tumors comprising $<1 \%$ of all malignancies. The age adjusted annual incidence rate in Finland is 2.3 per 100,000 person-years. STS are a heterogeneous group of tumors and are histopathologically subdivided into 15 categories. In general, STS are considered as one group despite of differences in biological behavior.

STS grow in an infiltrating manner, but they respect thick fascias as natural barriers for disease spread. STS are usually surrounded by a pseudocapsule consisting of connective tissue and tumor cells. Microscopic satellite metastases often extend outside this pseudocapsule. Because of these reasons, surgical excision margins are large and usually lead to massive tissue defects. Plastic surgical reconstructions are often needed. Local recurrences cause abundant morbidity for the patients, although the survival is predominantly determined by hematogenous metastases. With current multidisciplinary treatment, local recurrences occur in 13 to $23 \%$ of the patients (1-3). Approximately $80 \%$ of the local recurrences occur within 2 years after the initial treatment and are usually treated operatively.

At present, little is known about local genetic progression of STS. Few reports about cytogenetic changes in primary and locally recurrent STS can be found (4-6). Genetic changes in primary sarcomas and their pulmonary metastases have been previously studied by us (7). To our knowledge, larger 
series about genetic changes in primary and locally recurrent soft-tissue sarcoma, studied by comparative genomic hybridization (CGH), have not been reported. In the present study, we used paired samples of primary tumors and their subsequent local recurrences for CGH analyzes. CGH detects alterations in DNA sequence copy number, in other words, gains, losses, and high-level amplifications, screening the whole tumor genome in a single hybridization (8). Comparisons between a primary tumor and its local recurrence offer a longitudinal view into tumor progression.

\section{MATERIALS AND METHODS}

\section{Materials}

The material consisted of 20 patients, whose primary soft-tissue sarcoma and its corresponding, subsequent local recurrence were studied by CGH (Table 1). The patients were identified through the registry of the Soft Tissue Sarcoma Group at the Helsinki University Central Hospital. When the material was collected, the local recurrences were selected by the following criteria: time from the first operation to the detection of the tumor recurrence was $>4$ months, and all macroscopic tumor mass had been excised in the first operation. Patients who received chemo- and/or radiotherapy before the operation of primary tumor or local recurrence were excluded.

The primary tumor specimens were from paraffin-embedded tissue samples in 19 cases and from freshly frozen tissue in one case. In local recurrences, specimens were obtained from paraffin-embedded tissue in 14 cases and from freshly frozen tissue in 6 cases. The most representative block of tumor tissue was chosen for CGH analysis by light-microscopic examination.

There were eight malignant fibrous histiocytomas (MFH), three fibrosarcomas, two leiomyosarcomas, two liposarcomas, three synovial sarcomas, and 2 unclassified sarcomas. All tumors were located in limbs or trunk. Tumor malignancy was graded on a four-grade scale (1 to 2, low grade, 3 to 4 , high grade; 9,10 ). Malignancy grade was high in $14 / 20$ and low in $6 / 20$ of the tumors. In Case 10, the malignancy grade progressed from Grade 1 in the primary tumor to Grade 4 in the local recurrence. In the other pairs, the histopathologic malignancy grade did not change between the primary tumor and the local recurrence. The mean time from primary to locally recurrent tumor was 31 months (range, 4 to 95 months).

\section{METHODS}

DNA isolation was performed by standard methods $(11,12)$. CGH was performed as described elsewhere (13) with a modification of using fluorochromes conjugated to a mixture of dUTP and dCTP in nick translation (14). Briefly, tumor DNA was labeled with fluorescein isothiocyanate-dCTP and -dUTP mixture (NEL, Reno, NV) and normal, sex-matched DNA with Texas red-dCTP and -dUTP mixture (NEL) by nick translation. The hybridization mixture contained $1 \mu \mathrm{g}$ of labeled tumor DNA, $1 \mu \mathrm{g}$ of labeled normal DNA, and $20 \mu \mathrm{L}$ of cot-1-

TABLE 1. Clinical and Histopathologic Data of 20 Patients with a Locally Recurrent Soft-Tissue Sarcoma

\begin{tabular}{|c|c|c|c|c|c|c|c|c|c|c|}
\hline \multirow{2}{*}{$\begin{array}{l}\text { Patient } \\
\text { No. }\end{array}$} & \multirow[b]{2}{*}{ Sex } & \multirow[b]{2}{*}{ Age } & \multirow{2}{*}{$\begin{array}{l}\text { Histopathologic } \\
\text { Diagnosis }\end{array}$} & \multirow[b]{2}{*}{ Grade } & \multicolumn{2}{|c|}{ Size $(\mathrm{cm})$} & \multirow[b]{2}{*}{ Site } & \multicolumn{2}{|c|}{ Sample } & \multirow{2}{*}{$\begin{array}{l}\text { Time to Local } \\
\text { Recurrence } \\
\text { (months) }\end{array}$} \\
\hline & & & & & Primary & $\begin{array}{c}\text { Local } \\
\text { Recurrence }\end{array}$ & & Primary & $\begin{array}{c}\text { Local } \\
\text { Recurrence }\end{array}$ & \\
\hline 1 & M & 70 & MFH & 2 & 5 & 3 & Lower leg & $\mathrm{P}$ & $\mathrm{P}$ & 17 \\
\hline 2 & M & 40 & MFH & 3 & 5 & 2 & Shoulder & $\mathrm{P}$ & $\mathrm{F}$ & 11 \\
\hline 3 & M & 80 & $\mathrm{MFH}$ & 3 & 3 & 6 & Lower leg & $\mathrm{P}$ & $\mathrm{P}$ & 17 \\
\hline 4 & M & 68 & MFH & 3 & 2.2 & 2.5 & Lower leg & $\mathrm{P}$ & $\mathrm{F}$ & 22 \\
\hline 5 & $\mathrm{~F}$ & 76 & MFH & 3 & 4 & 1.8 & Upper arm & $\mathrm{P}$ & $\mathrm{P}$ & 65 \\
\hline 6 & M & 60 & MFH & 4 & 5 & 3.2 & Lower leg & $\mathrm{P}$ & $\mathrm{F}$ & 40 \\
\hline 7 & $\mathrm{M}$ & 82 & $\mathrm{MFH}$ & 4 & 4.8 & 20 & Lower leg & $\mathrm{P}$ & $\mathrm{F}$ & 13 \\
\hline 8 & $\mathrm{~F}$ & 84 & MFH & 4 & 6.5 & 7 & Upper arm & $\mathrm{P}$ & $\mathrm{F}$ & 4 \\
\hline 9 & M & 53 & Fibrosarcoma & 1 & NA & NA & Shoulder & $\mathrm{P}$ & $\mathrm{P}$ & 95 \\
\hline 10 & $\mathrm{~F}$ & 51 & Fibrosarcoma & $1^{a}$ & 4 & 6.2 & Upper arm & $\mathrm{P}$ & $\mathrm{P}$ & 40 \\
\hline 11 & $\mathrm{M}$ & 50 & Fibrosarcoma & 3 & 5 & 10 & Shoulder & $\mathrm{P}$ & $\mathrm{P}$ & 75 \\
\hline 12 & M & 39 & Leiomyosarcoma & 3 & 14 & 11.5 & Lower leg & $\mathrm{P}$ & $\mathrm{P}$ & 17 \\
\hline 13 & $\mathrm{~F}$ & 88 & Leiomyosarcoma & 3 & 10 & 8 & Lower leg & $\mathrm{P}$ & $\mathrm{P}$ & 10 \\
\hline 14 & $\mathrm{~F}$ & 64 & Lipoma-like liposarcoma & 1 & 11 & 6 & Upper arm & $\mathrm{F}$ & $\mathrm{F}$ & 12 \\
\hline 15 & M & 41 & Myxoid liposarcoma & 2 & 16 & 8 & Lower leg & $\mathrm{P}$ & $\mathrm{P}$ & 11 \\
\hline 16 & M & 23 & Synovial sarcoma & 3 & 5 & 5 & Upper trunk & $\mathrm{P}$ & $\mathrm{P}$ & 67 \\
\hline 17 & $\mathrm{~F}$ & 38 & Synovial sarcoma & 3 & 5 & 2.5 & Knee & $\mathrm{P}$ & $\mathrm{P}$ & 32 \\
\hline 18 & $\mathrm{~F}$ & 29 & Synovial sarcoma & 3 & 7 & 7 & Knee & $\mathrm{P}$ & $\mathrm{P}$ & 54 \\
\hline 19 & M & 69 & Sarcoma NOS & 1 & 2.5 & 0.5 & Knee & $\mathrm{P}$ & $\mathrm{P}$ & 13 \\
\hline 20 & M & 59 & Sarcoma NOS & 4 & 2 & 5 & Upper arm & $\mathrm{P}$ & $\mathrm{P}$ & 8 \\
\hline
\end{tabular}

${ }^{a}$ In this tumor pair, the grade of primary tumor was 1 and local recurrence, 4 . In all other pairs, the histologic grade remained the same. MFH, malignant fibrous histiocytoma; P, paraffin-embedded tissue; F, freshly frozen tissue; NA, not available. 
DNA (Gibco BRL, Life Technologies, Gaithersburg, MD) dissolved in $10 \mu \mathrm{L}$ of hybridization buffer.

Hybridizations on normal human metaphase spreads were carried out in 2-3 days. After washes, the chromosomes were counterstained with DAPI in an antifade solution. Hybridizations were analyzed using an Olympus fluorescence microscope and the ISIS digital image analysis system (MetaSystems GmbH, Altlussheim, Germany) based on an integrated high-sensitivity CCD camera and automated CGH analysis software. Three-color images (green for tumor DNA, red for normal DNA, and blue for DAPI) were captured from 12 metaphases in each sample. Chromosomal regions were interpreted as overrepresented when the green-to-red ratio was $>1.17$ (gains) and as underrepresented when the ratio was $<0.85$ (losses). These limits were based on our earlier results and on the control experiments: in each experiment, a negative control (two differentially labeled normal human DNAs) and a positive control (a tumor sample with known DNA sequence copy number changes) were included. Gains exceeding the 1.5 limit were termed high-level amplifications (for a review on amplifications detected in different neoplasms by $\mathrm{CGH}$, the 1.5 threshold and the sensitivity of $\mathrm{CGH}$, see 15 , also available at http://www.helsinki.fi/ lgl_www/CMG.html).

\section{RESULTS}

\section{Overview of Results and Mean Number of Changes}

Fifty percent $(10 / 20)$ of the primary tumors showed copy number aberrations. The mean number of copy number aberrations per tumor in primary sarcomas was 2.45 (range, 0 to 11). The mean numbers of gains, losses, and high-level amplifications in primary tumors were $1.45,1.0$, and 0.4 , respectively. In local recurrences, copy number aberrations were detected in $70 \%(14 / 20)$ of the tumors. The total amount of aberrations in local recurrences was more than two times that in primary tumors, with the mean number of copy number aberrations being 5.05 (range, 0 to 17) and the mean numbers of gains, losses, and high-level amplifications being 3.3, 1.75, and 0.8 , respectively.

The difference in copy number aberrations between primary tumors and local recurrences was calculated and statistically analyzed by a paired $t$ test. The increase of copy number changes from primary tumors to local recurrences was statistically significant $(P=.02$, mean number of difference [MND], 2.6, 95\% confidence interval (CI) $0.46-$ 4.74). The increase of gains from primary tumors to local recurrences was also significant $(P=.03$, MND 1.85, CI 0.18-3.52). The increase of losses showed no statistical significance.
In 10 tumor pairs, the number of aberrations was greater in local recurrences than in primary tumors (Table 2). In three pairs, more aberrations were detected in primary tumors than in their local recurrences. In two pairs, the number of aberrations was equal in primary and locally recurrent tumors. In five pairs, CGH detected no copy number changes in primary tumor nor in its local recurrence: two MFHs G3, two synovial sarcomas G3, and one myxoid liposarcoma G2. Of all the samples, CGH showed no changes in 10 primary tumors and 6 local recurrences.

The mean number of changes was different between high-grade (Grades 3 and 4) and low-grade (Grades 1 and 2) tumors. The mean number of changes was 2.45 in primary tumors and 5.05 in local recurrences. When these groups were further divided into low- and high-grade tumors, values were, in primary tumors, 2.5 and 2.4 , and in local recurrences, 2.8 and 5.8, respectively. These numbers reflect that in primary tumors, the low- and high-grade malignant sarcomas contain an equal amount of copy number changes, whereas in local recurrences, the mean number of changes increases more than twofold in high-grade tumors.

The tumors were also divided into translocationassociated and non-translocation-associated sarcomas. In the translocation-associated group $(n=4)$, there were one myxoid liposarcoma and three synovial sarcomas. In the non-translocation-associated group ( $n=16$ ), there were eight MFHs, three fibrosarcomas, two leiomyosarcomas, one lipoma-like liposarcoma, and two sarcomas NOS. In the translocation-associated group, the mean number of changes per primary tumor was 0.25 ; the value was the same for local recurrences. In the nontranslocation-associated group, the mean number of changes per tumor was 3.1 in primary tumors; in local recurrences it was 6.3. Thus, in the translocationassociated group, the number of changes did not change from primary to locally recurrent tumors, whereas in the non-translocation-associated group, it increased twofold.

\section{Most Frequent Gains, Losses, and High-Level Amplifications}

The most frequent copy number change was loss at $9 p$ with the minimal common region of 9p22pter. This occurred in $30 \%$ of the local recurrences (Table 3, Fig. 1). In only one (5\%) primary tumor, a loss affecting 9p21-pter was detected. The second frequent copy number changes were gains at $5 p$ (minimal common region 5p14-15.1) and 20q, which both occurred in $25 \%$ of local recurrences. In primary tumors there were gains of $5 p$ in $10 \%$ and of the whole chromosome 20 in $5 \%$. The most frequent copy number changes that affected both pri- 
TABLE 2. Copy Number Karyotypes of 20 Primary Soft Tissue Sarcomas and Their Local Recurrences by Comparative Genomic Hybridization

\begin{tabular}{|c|c|c|c|}
\hline \multirow{2}{*}{$\begin{array}{l}\text { Patient } \\
\text { No. }\end{array}$} & \multirow{2}{*}{$\begin{array}{l}\text { Histopathologic } \\
\text { Diagnosis }\end{array}$} & \multicolumn{2}{|c|}{ Copy Number Karyotypes } \\
\hline & & Primary Tumor & Local Recurrence \\
\hline 1 & MFH G2 & $\begin{array}{l}+5 \mathrm{p} /++5 \mathrm{p} 15.2 \text {-pter, }+7 \mathrm{p} 12 \text {-pter, +8q12- } \\
\text { 21.3, +9q21-qter, -13q14-qter }\end{array}$ & $+5 p,+7 p,-13 q 13$-qter \\
\hline 2 & MFH G3 & $\mathrm{N}$ & $\begin{array}{l}\text { +1pter-q31, +7p11.2-pter, -12p11.2-pter, } \\
\quad+\text { Xpter-q12 }\end{array}$ \\
\hline 3 & MFH G3 & $\mathrm{N}$ & $\mathrm{N}$ \\
\hline 4 & MFH G3 & $\mathrm{N}$ & $\begin{array}{l}+4 \mathrm{p},-5 \text { pter-q23, +6q22-qter, }+7 \mathrm{p},-9 \mathrm{p} 12 \text {-pter } \\
+11 \text { cen-q14, }-13 \mathrm{q} 21-32,+18 \mathrm{p} /++18 \mathrm{p} 11.3 \\
\quad+19 \mathrm{q},+20,+22 \mathrm{q} /++22 \mathrm{q} 11.2\end{array}$ \\
\hline 5 & MFH G3 & $\mathrm{N}$ & $\mathrm{N}$ \\
\hline 6 & MFH G4 & $\mathrm{N}$ & $+11 q 14-23$ \\
\hline 7 & MFH G4 & $\begin{array}{l}+1 \mathrm{q} 21-23 /++1 \mathrm{q} 21,+5 \mathrm{p} /++5 \mathrm{p} 13,+6 \\
\quad+7 \mathrm{pter}-\mathrm{q} 11.2 /++7 \mathrm{p} 11.2-21,-8 \mathrm{p} 12-\mathrm{pter} \\
\quad+9 \mathrm{q},-11 \mathrm{p} 13 \text {-pter, }-13 \mathrm{q} 12-31,+14 \mathrm{q} \\
\quad-16 \mathrm{q} 22 \text {-qter, +17pter-q11.2/ } \\
++17 \mathrm{p} 11.2-12\end{array}$ & $\begin{array}{l}+1 \mathrm{q} 21-25 /++1 \mathrm{q} 21-23,+5 \mathrm{p} /++5 \mathrm{p} 12-14,+6 / \\
++6 \mathrm{p} 23-\mathrm{pter},+7 /++7 \mathrm{p} 11.2-15,-8 \mathrm{p} 12-\mathrm{pter} \\
\quad-9 \mathrm{p} 21-\mathrm{pter},+9 \mathrm{p} 12-\mathrm{qter},-13 \mathrm{q} 14-31,+13 \mathrm{q} 32- \\
\\
\text { qter, }+14 \mathrm{q},+15 \mathrm{q},+17 /++17 \mathrm{p} 13-\mathrm{q} 12,+18 \mathrm{pter}- \\
\text { q11.2/++18p, +Xp22.1-pter }\end{array}$ \\
\hline 8 & MFH G4 & $\begin{array}{l}+1 \mathrm{p} 31-33,+6 \mathrm{q} 21 \text {-qter, +7q31-qter, } \\
+15 \mathrm{q} 11.2-22\end{array}$ & $\mathrm{~N}$ \\
\hline 9 & Fibrosarcoma G1 & $\mathrm{N}$ & $+1 \mathrm{p} 31-33,+1 \mathrm{q} 21-23,+12 \mathrm{q} 15-21$ \\
\hline 10 & Fibrosarcoma G1 ${ }^{a}$ & $\mathrm{~N}$ & $\begin{array}{l}+4 \mathrm{q} 26 \text {-qter, +5cen-p15.1, -5q14-qter, }-9 \mathrm{p} 21- \\
\text { pter, }-10,-12 \text { pter-q21, }-17 \mathrm{p} 11.2 \text {-pter, } \\
\quad-20 \mathrm{p} 11.2 \text {-pter, }-21 \mathrm{q},-\mathrm{Xq}\end{array}$ \\
\hline 11 & Fibrosarcoma G3 & $\begin{array}{l}-1 \text { q23-qter, -2p12-pter, +4p13-pter, } \\
\text {-8p11.2-pter, -10pter-q22, - 12p11.2- } \\
\text { pter, +13q22-qter, +15q22-qter, } \\
\text { +17pter-q12, -20p }\end{array}$ & $\begin{array}{l}\text { +1cen-p36.1/++1p31, +2p11.2-q22,-3p14- } \\
\text { q13.3,-4p13-15.3,-4q22-31.1, +5p14-pter/ } \\
++5 \mathrm{p} 15.3,-8 \mathrm{p},-9 \mathrm{p} 12-\mathrm{pter},+14 \mathrm{q} 21-\mathrm{qter} \\
+15 \mathrm{q} 21-\mathrm{qter} /++15 \mathrm{q} 22-24,+16 \mathrm{p} 11.2-\mathrm{pter},+17 \\
+18 \mathrm{p} /++18 \mathrm{p} 11.3,-18 \mathrm{q} 21-\mathrm{qter},+19 \mathrm{p},-20 \mathrm{p}, \\
+20 \mathrm{q}\end{array}$ \\
\hline 12 & Leiomyosarcoma G3 & +7 & -9 p22-pter, $+12,+19,+20,+21 q,++22 q$ \\
\hline 13 & Leiomyosarcoma G3 & $-10 p 11.2-$ pter, $-13 q 21,-16 q,+17 p$ & $\begin{array}{l}+2 \mathrm{q} 12-21,+3 \mathrm{p} 23 \text {-pter, }-4 \mathrm{q},+5 \mathrm{p} 13-\mathrm{pter},-6 \mathrm{p} 22- \\
\text { pter, }+8 \mathrm{p} 12 \text {-pter, }+8 \mathrm{q} 24.1 \text {-qter, }+9,-10 \mathrm{q} \\
\quad-13 \mathrm{q} 21,+14 \mathrm{q} 11.2-13,+15 \mathrm{q},+16 \mathrm{p} 12-13.1 \\
+17 /++17 \mathrm{p},-18 \mathrm{q},+20,+ \text { Xcen-p22.1 }\end{array}$ \\
\hline 14 & $\begin{array}{l}\text { Lipoma-like } \\
\text { liposarcoma G1 }\end{array}$ & $\begin{array}{l}+1 \mathrm{q} 21-24 /++1 \mathrm{q} 21,+3 \mathrm{q} 13.2-25 /++3 \mathrm{q} 22, \\
+12 \mathrm{q} 13-23 /++12 \mathrm{q} 14-21,+22 \mathrm{q} 11.2-\mathrm{qter}\end{array}$ & $+12 \mathrm{q} 13-23 /++12 \mathrm{q} 13-21,+22 \mathrm{q} 12-\mathrm{qter}$ \\
\hline 15 & Myxoid liposarcoma G2 & $\mathrm{N}$ & $\mathrm{N}$ \\
\hline 16 & Synovial sarcoma G3 & $\mathrm{N}$ & $\mathrm{N}$ \\
\hline 17 & Synovial sarcoma G3 & +2 & +2 \\
\hline 18 & Synovial sarcoma G3 & $\mathrm{N}$ & $\mathrm{N}$ \\
\hline 19 & Sarcoma NOS G1 & $\begin{array}{l}\text {-1p13-pter, -3p13-pter, -3q13.3-qter, } \\
-8 \text { p12-pter, }-9 \text { p21-pter, }-22 q\end{array}$ & $\begin{array}{l}\text {-1p22-pter, }-3 p 14 \text {-pter, -3q21-qter, -8p12-pter, } \\
-9 \text { p21-pter, }-22 q\end{array}$ \\
\hline 20 & Sarcoma NOS G4 & $+8 \mathrm{q} 21.1$-qter, $+17 \mathrm{q} 21$-qter, +20 & $\begin{array}{l}+1 \mathrm{q} 21 \text {-qter } /++1 \mathrm{q} 31 \text {-qter, }+8 \mathrm{q} 12 \text {-qter, }+15 \mathrm{q} 24 \text { - } \\
\text { qter, +16p11.2-pter, +17q21-qter, }+20\end{array}$ \\
\hline
\end{tabular}

${ }^{a}$ In this tumor pair, the grade of primary tumor was 1 and local recurrence, 4 . In all other pairs, the histologic grade remained the same.

G, malignancy grade; N, normal; +, gain of DNA sequence copy number; ++ , high-level amplification; - , loss.

mary tumors and local recurrences with almost the same frequencies were gain at $7 \mathrm{p}$ with minimal common region of $7 \mathrm{p} 12$-pter in primary tumors (15\%) and 7p11.2-pter in local recurrences $(20 \%)$, and losses of $13 \mathrm{q} 21$ and 8 p12-pter $(15 \%$ and $20 \%$; $15 \%$ and $15 \%$, respectively).

The most frequent high-level amplification at 18 p11.3 was detected in $15 \%$ of the local recurrences but in none of the primary tumors. Recurrent high-level amplifications were also seen at $17 \mathrm{p}$ (primary tumors, 5\%; local recurrences, 10\%), 22q11.2 (local recurrences, 10\%), 1q21 (primary tumors, 10\%) and 1q21-23 (local recurrences, 5\%).

\section{Clonal Relationship}

Of the pairs in which both samples had aberrations by CGH $(n=9)$, only two pairs shared identical aberrations, although in the other, the length of some aberrations had changed. One pair did not have any common changes. In the rest of the pairs, common changes outnumbered the differences in two pairs, and the differences outnumbered the common changes in two pairs. In two pairs, the number of common changes and differences was identical.

\section{DISCUSSION}

In the present study, we performed a genomewide survey by CGH of primary STS and their local recurrences. Fifty percent of the pairs showed more aberrations in the locally recurrent tumor than in the primary tumor. More than a twofold increase in the number of copy number aberrations was detected in local recurrences, although the histopathologic grade did not change in 19 of 20 tumor 
TABLE 3. Most Frequent Copy Number Changes in 20 Pairs of Primary Soft-Tissue Sarcomas and Their Local

\begin{tabular}{|c|c|c|c|c|c|}
\hline \multicolumn{3}{|c|}{ Primary Tumors } & \multicolumn{3}{|c|}{ Local Recurrences } \\
\hline Mcr & $n$ & $\%$ & Mcr & $n$ & $\%$ \\
\hline \multicolumn{6}{|l|}{ Gains and losses } \\
\hline-9 p21-pter & 1 & 5 & -9p22-pter & 6 & 30 \\
\hline$+5 p$ & 2 & 10 & $+5 p 14-p 15.1$ & 5 & 25 \\
\hline+20 & 1 & 5 & $+20 q$ & 5 & 25 \\
\hline$+1 q 21-23$ & 2 & 10 & $+1 q 21-23$ & 4 & 20 \\
\hline$+7 \mathrm{p} 12$-pter & 3 & 15 & $+7 \mathrm{p} 11.2$-pter & 4 & 20 \\
\hline -8p12-pter & 3 & 15 & -8p12-pter & 3 & 15 \\
\hline$-13 q 21$ & 3 & 15 & $-13 q 21$ & 4 & 20 \\
\hline$+15 q 24-q t e r$ & 1 & 5 & +15q24-qter & 4 & 20 \\
\hline$(+15 q 22)$ & (2) & (10) & & & \\
\hline$+17 p$ & 3 & 15 & $+17 \mathrm{p}$ & 3 & 15 \\
\hline$+17 \mathrm{q} 21$-qter & 1 & 5 & +17q21-qter & 4 & 20 \\
\hline$+16 \mathrm{p} 12-13.1$ & 0 & 0 & +16p12-13.1 & 3 & 15 \\
\hline \multicolumn{6}{|c|}{ High-level amplifications } \\
\hline$++18 \mathrm{p} 11.3$ & 0 & 0 & $++18 \mathrm{p} 11.3$ & 3 & 15 \\
\hline$++1 \mathrm{q} 21$ & 2 & 10 & $++1 \mathrm{q} 21-23$ & 1 & 5 \\
\hline$++17 \mathrm{p} 11.2-12$ & 1 & 5 & $++17 p$ & 2 & 10 \\
\hline$++22 q 11.2$ & 0 & 0 & $++22 \mathrm{q} 11.2$ & 2 & 10 \\
\hline
\end{tabular}

Mcr, minimal common region; +, Gain of DNA sequence copy number; -, loss; ++, high-level amplification.

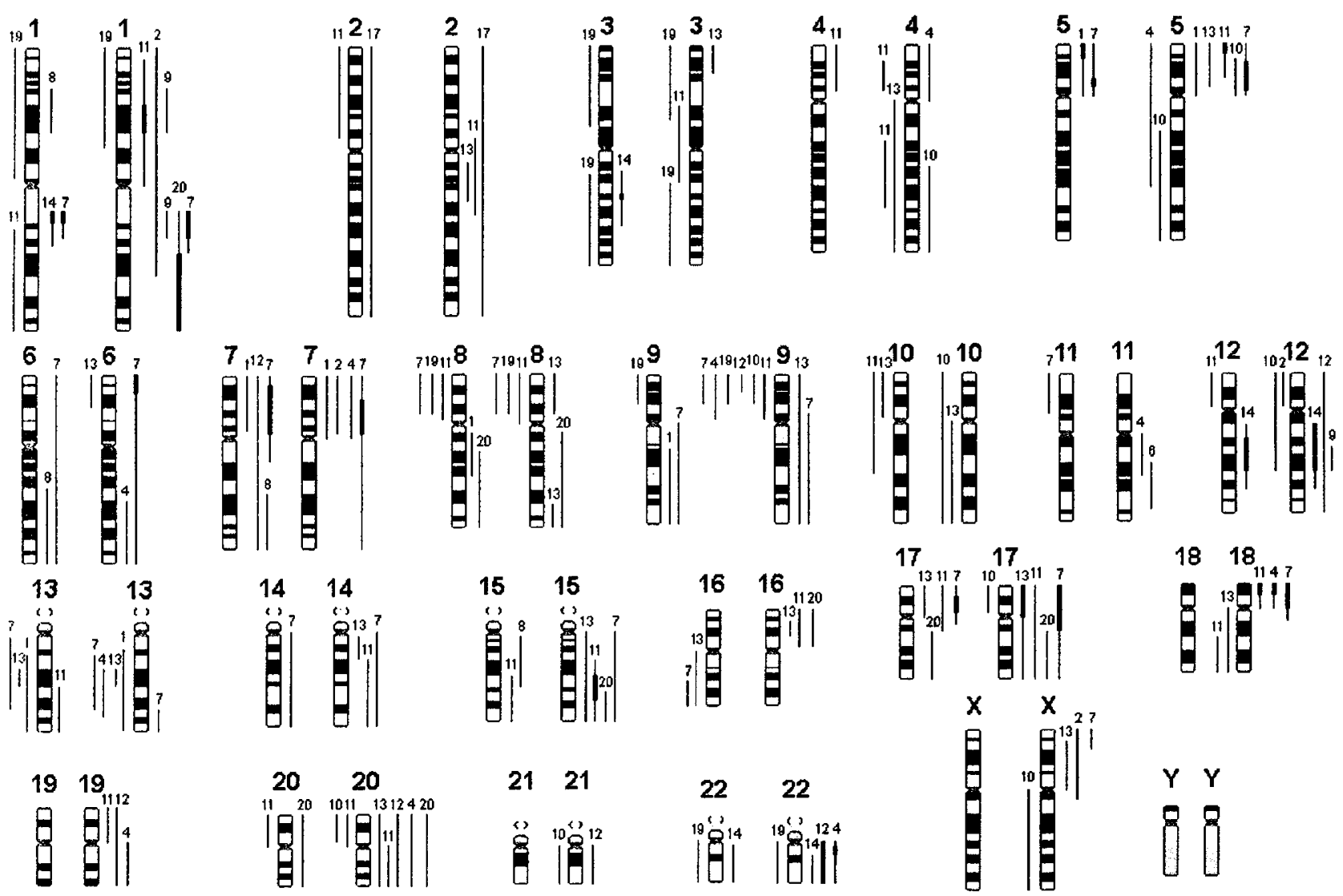

FIGURE 1. Summary of DNA gains, losses, and high-level amplifications in 20 pairs of primary soft-tissue sarcomas and their local recurrences analyzed by CGH. In each pair of chromosomes, the one on the left symbolizes primary tumor and the one on the right, local recurrence. The lines to the left of each chromosome are DNA losses, and to the right, gains. High-level amplifications are shown with thick lines. Small numbers refer to samples in Table 1.

pairs. These findings suggest that tumor progression from primary to locally recurrent tumor may be associated with an increase of genetic changes and that local recurrences are thus more advanced than primary tumors. An increase of copy number aberrations in local recurrences studied by CGH has also been found in prostate cancer (16) and in in situ ductal breast carcinomas (17). Furthermore, an evolution of a fibrosarcoma was followed by cytogenetic methods over a period of 26 months, 
and it was found that chromosomal aberrations increased in parallel with the clinical and histopathologic tumor progression (5). Nevertheless, in our study, one primary synovial sarcoma maintained its copy number karyotype, gain of chromosome 2, identically in the local recurrence over a period of 32 months.

An increase in copy number aberrations from a primary tumor to a metastasis, studied by CGH, has been detected in breast cancer (18) and sarcomas (7). Specific alterations for metastatic tumors have not been detected in sarcomas (7), breast cancer (18), or small-cell lung carcinomas (19), although these have been suggested in renal clear cell carcinomas (20).

In the present study, gains predominated over losses in primary tumors with a ratio of 3:2. In local recurrences, a similar trend was detected with a ratio of 13:7. The number of high-level amplifications was twice as high in local recurrences as in primary tumors. A loss at $9 \mathrm{p}$ with the minimal common region 9p22-pter was the most common copy number change occurring in $30 \%$ of the local recurrences but only in $5 \%$ of the primary tumors. Thus, a clear increase of the losses at $9 p$ was detected in local recurrences compared to primary tumors. $9 p$ losses are very frequent in various human neoplasms (for a review, see 21).

Gains at $5 p$ were relatively frequent, seen in $10 \%$ of primary tumors and in $25 \%$ of local recurrences. Also, high-level amplifications at $5 p$ were seen, but these were not recurrent. Gains and high-level amplifications at $5 p$ are often seen in sarcomas and carcinomas of different subtypes (15). The increase of gains was also detected at 20q, occurring in $5 \%$ of the primary tumors and $25 \%$ of the local recurrences. High-level amplification in $18 p$ was detected in three local recurrences but in none of the primary tumors. The histopathologic diagnosis for these recurrences were two MFHs and one fibrosarcoma.

A gain with the minimal overlapping region of 1q21-23 occurred in two primary tumors and four local recurrences, with a high-level amplification at $1 \mathrm{q} 21$ in two primary tumors and at 1q21-23 in one local recurrence. Several genes of potential significance in sarcoma development or progression have been mapped in this region, such as OTF1, NTRK1, SPRR family, and S100 family (15).

Quantitative changes, for example in which a gain changed into a high-level amplification or the length of a change increased, occurred in several tumor pairs. It was also noted that frequently, an aberration in one of the samples was seen as a "trend" in the other sample but not exceeding the thresholds for gain or loss. Similar observations have been made by us previously (7).
CGH detected no changes in 16 samples. Of these, 15 were paraffin-embedded samples and 1 was a freshly frozen tissue sample, so it is not likely that the normal copy number karyotype was due to a nonrepresentative sample. An explanation for the normal finding may be intratumoral variation with multiple subclones. CGH detects only clonal changes. The aberrations in subclones may also balance one another, thus giving a normal result by CGH. It is also possible that the copy number aberrations were too small to be detected by CGH. CGH does not detect balanced aberrations, so a tumor with only a specific translocation will appear normal by CGH. This could explain why no aberrations were detected by CGH in Cases 15, 16 , and 18.

Although specific alterations for local recurrence were not detected, our study confirms that an increasing amount of DNA sequence copy number aberrations is a dominant feature in the progression from a primary tumor to a local recurrence.

\section{REFERENCES}

1. Suit HD, Mankin HJ, Wood WC, Gebhardt MC, Harmon DC, Rosenberg A, et al. Treatment of the patient with stage M0 soft tissue sarcoma. J Clin Oncol 1988;6:854-62.

2. Popov P, Tukiainen E, Asko-Seljavaara S, Huuhtanen R, Virolainen $\mathrm{M}$, Virkkunen $\mathrm{P}$, et al. Soft tissue sarcomas of the lower extremity: surgical treatment and outcome. Eur J Surg Oncol 2000;26:679-85.

3. Vraa S, Keller J, Nielsen OS, Sneppen O, Jurik AG, Jensen OM. Prognostic factors in soft tissue sarcomas: the Aarhus experience. Eur J Cancer 1998;34:1876-82.

4. Örndal C, Mandahl N, Willén H, Rydholm A, Mitelman F. Cytogenetic evolution in primary tumors, local recurrences, and pulmonary metastases of two soft tissue sarcomas. Clin Exp Metastasis 1993;11:401-8.

5. Örndal C, Mandahl N, Willén H, Carlen B, Heim S, Mitelman F. Cytogenetic heterogeneity and clonal evolution in a recurrent fibrosarcoma. J Exp Clin Cancer Res 1993;12: 23-31.

6. Mandahl N, Heim S, Arheden K, Rydholm A, Willén H, Mitelman F. Separate karyotypic features in a local recurrence and a metastasis of a fibrosarcoma. Cancer Genet Cytogenet 1989;37:139-40.

7. Tarkkanen M, Huuhtanen R, Virolainen M, Wiklund T, AskoSeljavaara S, Tukiainen E, et al. Comparison of genetic changes in primary sarcomas and their pulmonary metastases. Genes Chromosom Cancer 1999;25:323-31.

8. Kallioniemi A, Kallioniemi O-P, Sudar D, Rutovitz D, Gray JW, Waldman F, Pinkel D. Comparative genomic hybridization for molecular cytogenetic analysis of solid tumours. Science 1992;258:818-21.

9. Markhede G, Angervall L, Stener B. A multivariate analysis of the prognosis after surgical treatment of malignant soft tissue tumors. Cancer 1982;49:1721-33.

10. Alvegård TA, Berg NO. Histopathology peer review of highgrade soft tissue sarcoma: the Scandinavian Sarcoma Group experience. J Clin Oncol 1989;7:1845-51.

11. Miller SA, Dykes DD, Polesky HF. A simple salting out procedure for extracting DNAs from human nucleated cells. Nucleic Acids Res 1988;16:1215. 
12. Sambrook J, Fritsch EF, Maniatis T. In: Molecular cloning. A laboratory manual. New York: Cold Spring Harbor Laboratory Press; 1989.

13. Larramendy ML, Tarkkanen M, Valle J, Kivioja AH, Ervasti H, Karaharju E, et al. Gains, losses and amplifications of DNA sequences evaluated by comparative genomic hybridization in chondrosarcomas. Am J Pathol 1997;150:685-91.

14. El-Rifai W, Larramendy M, Björkqvist A-M, Hemmer S, Knuutila S. Optimization of comparative genomic hybridization using fluorochrome conjugated to dCTP and dUTP nucleotides. Lab Invest 1997;77:699-700.

15. Knuutila S, Björkqvist A-M, Autio K, Tarkkanen M, Wolf M, Monni $\mathrm{O}$, et al. DNA copy number amplifications in human neoplasms. Am J Pathol 1998;152:1107-23.

16. Visakorpi T, Kallioniemi AH, Syvänen A-C, Hyytinen ER, Karhu R, Tammela T, et al. Genetic changes in primary and recurrent prostate cancer by comparative genomic hybridization. Cancer Res 1995;55:342-47.

17. Waldman FM, DeVries S, Chew KL, Moore DH II, Kerlikowske K, Ljung B-M. Chromosomal alterations in ductal carcinomas in situ and their in situ recurrences. J Natl Cancer Inst 2000;92:313-20.

18. Nishizaki T, DeVries S, Chew K, Goodson WH III, Ljung B-M, Thor A, et al. Genetic alterations in primary breast cancers and their metastases: direct comparison using modified comparative genomic hybridization. Genes Chromosom Cancer 1997;19:267-72.

19. Schwendel A, Langreck H, Reichel M, Schröck E, Ried T, Dietel M, et al. Primary small-cell lung carcinomas are characterized by a recurrent pattern of genetic alterations. Int J Cancer 1997;74:86-93.

20. Gronwald J, Störkel S, Holtgreve-Grez H, Hadaczek P, Brinkschmidt C, Jauch A, et al. Comparison of DNA gains and losses in primary renal clear cell carcinomas and metastatic sites: importance of $1 \mathrm{q}$ and $3 \mathrm{p}$ copy number changes in metastatic events. Cancer Res 1997;57:481-7.

21. Knuutila S, Aalto Y, Autio K, Björkqvist A-M, El-Rifai W, Hemmer S, et al. DNA copy number losses in human neoplasms. Am J Pathol 1999;155:683-94. 